UDC 327.56

Submitted: 10.02 .2019

LBC 66.4(0),3

Accepted: 10.07.2019

\title{
THEORY OF ULTRA-LONG WAR CYCLES BY V.L. TSYMBURSKY AS A TOOL OF MODERN GEOPOLITICALANALYSIS
}

\author{
Ilya L. Morozov \\ Volgograd Institute of Management, Branch of Russian Presidential Academy \\ of National Economy and Public Administration, Volgograd, Russian Federation
}

\begin{abstract}
Introduction. The purpose of this article is to return the concept of ultra-long military cycles (hereinafter referred to as ULMS) by Russian political scientist, philosopher and philologist Vadim L. Tsymbursky (1957-2009) to the methodological toolkit of modern political science and use it to identify potential key threats to the modern international security system. Methods and materials. The article makes a hypothesis about the early termination of the last of the ULMS selected by V.L. Tsymbursky, which began with the invention of a nuclear weapon in 1945 and was characterized by the predominance of possibilities of destruction over mobilization - the so-called "depressed" ULMS. This type of ULMS is characterized by the absence of large-scale long-lasting wars, the stability of the world political system. Analysis. The author of the article argues that under the influence of scientific and technical discoveries in the field of armaments (high-precision weapons combined with low-yield nuclear warheads, "swarm weapons", cybernetic weapons, biological weapons, the global missile defense system) and socio-political technologies (manipulating flows of refugees, "hybrid war", global weakening of national identities and social stratification of nations with the formation of "international elites"), the great powers are able to overcome the "nuclear impasse" and the world political system may enter the phase of increased risk of developing a full-scale world war. Results. In the coming decades, the world may enter the stage of an "expansive" ULMS, characterized by the return to the rate on mobilization resources as the main factor in the military-political confrontation. According to the author, one of the most effective ways to peacekeeping is the development of public diplomacy, multilateral international contacts at the level of non-state actors.
\end{abstract} relations.

Key words: ultra-long war cycle, mobilization, destruction, geopolitics, Tsymbursky, war, peace, international

Citation. Morozov I.L. Theory of Ultra-Long War Cycles by V.L. Tsymbursky as a Tool of Modern Geopolitical Analysis. Vestnik Volgogradskogo gosudarstvennogo universiteta. Seriya 4. Istoriya. Regionovedenie. Mezhdunarodnye otnosheniya [Science Journal of Volgograd State University. History. Area Studies. International Relations], 2019, vol. 24, no. 5, pp. 268-280. (in Russian). DOI: https://doi.org/10.15688/jvolsu4.2019.5.20

УДК 327.56

ББК $66.4(0), 3$

Дата поступления статьи: 10.02.2019

Дата принятия статьи: 10.07.2019

\section{ТЕОРИЯ СВЕРХДЛИННЫХ ВОЕННЫХ ЦИКЛОВ В.Л. ЦЫМБУРСКОГО КАК ИНСТРУМЕНТ СОВРЕМЕННОГО ГЕОПОЛИТИЧЕСКОГО АНАЛИЗА}

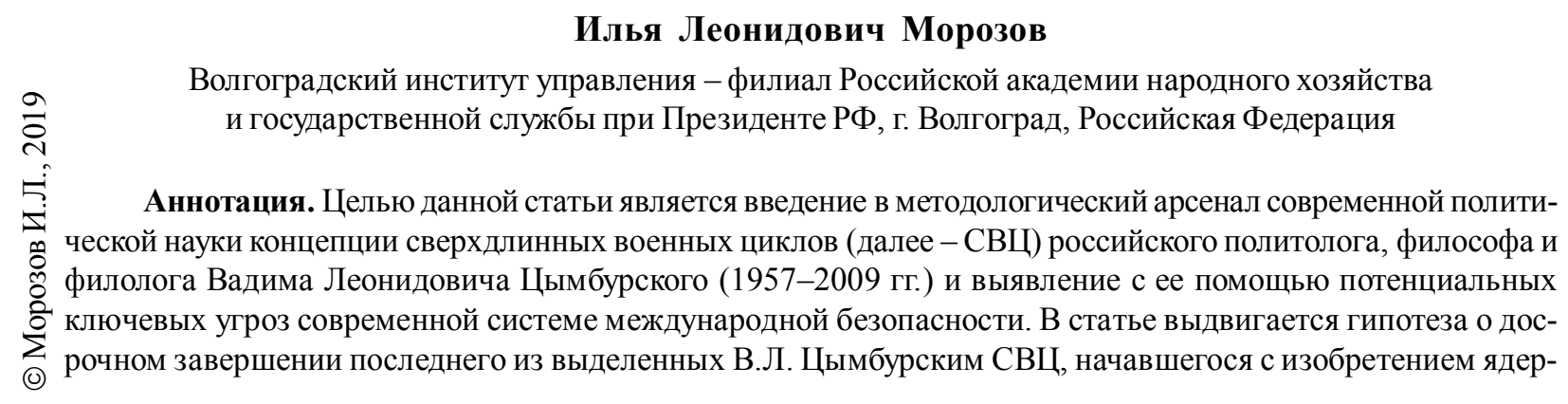


ного оружия в 1945 г. и характеризовавшегося преобладанием возможностей уничтожения над мобилизацией - так называемый «депрессивный» СВЦ. Последний характеризуется отсутствием широкомасштабных длительных войн, устойчивостью мировой политической системы. Автор статьи доказывает, что под воздействием научно-технических открытий в сфере вооружений (высокоточное оружие в сочетании с ядерными боезарядами пониженной мощности, «роевое» оружие, кибернетическое оружие, биологическое оружие, глобальная система противоракетной обороны) и социально-политических технологий (манипулирование потоками беженцев, «гибридная война», глобальное ослабление национальных идентичностей и социальное расслоение наций с формированием «интернационала элит») великие державы стоят на пороге преодоления «ядерного тупика» и входа мировой политической системы в фазу повышенного риска развития полномасштабной мировой войны. В ближайшие десятилетия мир может войти в стадию «экспансивного» СВЦ, характеризующегося возвращением к ставке на мобилизационные ресурсы как основному фактору в военно-политическом противоборстве. Один из эффективных способов сохранения мира автор статьи видит в развитии общественной дипломатии, многосторонних международных контактах на уровне негосударственных акторов.

Ключевые слова: сверхдлинный военный цикл, мобилизация, уничтожение, геополитика, Цымбурский, война, мир, международные отношения.

Цитирование. Морозов И. Л. Теория сверхдлинных военных циклов В.Л. Цымбурского как инструмент современного геополитического анализа // Вестник Волгоградского государственного университета. Серия 4, История. Регионоведение. Международные отношения. - 2019. - T. 24, № 5. - С. 268-280. - DOI: https:// doi.org/10.15688/jvolsu4.2019.5.20

Введение. Имя Вадима Леонидовича Цымбурского (1957-2009 гг.) является знаковым в истории отечественной политической науки. Расцвет интеллектуальной активности ученого пришелся на годы возрождения российской геополитики как субдисциплины политологического знания - 90-е гг. ХХ в., когда перед аналитиками актуализировались принципиально новые задачи поиска самоидентификации России в рамках нового миропорядка, заступающего на смену Ялтинско-Потсдамской международной системы. Потребовалось выявление связанных с ним потенциальных политических рисков, вызовов и угроз, корректировка российской практической геостратегии.

В.Л. Цымбурский откликнулся на новые вызовы меняющейся политической реальности разработкой нескольких взаимосвязанных геополитических теорий, потенциально применимых для анализа сложившейся ситуации с последующей разработкой новых принципов российской внешней политики, который сам ученый выполнить в полной мере не успел. Геополитическое наследие В.Л. Цымбурского включает в себя не только осмысление геополитики как политической субдисциплины и принципов реализации внешнеполитического курса государства [16], но и теорию «островного» характера российской цивилизации (уникальность, изолированность и противостояние), теорию циклов российского «похищения Европы» (несколько исторических попыток России военным или мирным путем стать обязательным, незаменимым, а по возможности и решающим элементом европейской международной системы), теорию СВЦ (закономерности влияния эволюции вооружений и мобилизационных технологий на мировую политику), а также ряд работ общего рода по истории международных и региональных политических систем [17; $18 ; 19]$. Если «островная» теория и ряд других концептуальных разработок В.Л. Цымбурского всегда оставались в фокусе научного внимания сообщества политологов [8], то концепция СВЦ сместилась на периферию и в политической науке практически не используется, хотя и упоминается в незначительном числе изданий публицистического характера.

Цель, которую ставит автор данной статьи, - вернуть в научный оборот концепцию СВЦ как инструмент анализа и прогноза современных геополитических тенденций развития межгосударственных отношений, выявить с его помощью потенциальные ключевые угрозы системе международной безопасности.

Метод. Используемая в данной статье теория СВЦ В.Л. Цымбурского, позволяющая выполнять изучение как исторических моделей, так и современных трендов военно-политичес- 
кого развития международной системы, может быть определена как синтез геополитического (К.Э. Сорокин, К.С. Гаджиев, Б.А. Исаев) и хронополитического (М.В. Ильин, А.С. Панарин, И.А. Чихарев, Е.Г. Пономарева, А.Л. Алюшин) подходов - геохронополитика.

Раскрывая общую суть теории СВЦ, В.Л. Цымбурский пишет: «За множеством факторов, относящихся к истории военного искусства и военного строительства, прослеживается единый паттерн: состязание возможностей мобилизации и уничтожения, со впечатляющей регулярностью протекающее так, что каждая сверхдлинная милитаристская волна проходит под главенством одной из этих возможностей, причем из четырех миновавших волн у трех - достоверная амплитуда в 150 лет» $[15$, с. $44-45]$.

СВЦ характеризуется сочетанием трех основных параметров:

1) способность политических элит мобилизовать на военные нужды людские и материальные ресурсы своего государства;

2) поражающая мощь основных видов вооружений ведущих государств;

3) понятие (эталон) победы, которое может быть выражено либо в ограниченном ослаблении противника для получения от него конкретных уступок, либо в полном уничтожении противника.

Под СВЦ можно понимать исторический период протяженностью в 150 лет, характеризующийся преобладающим эталоном военной победы, обусловленным соотношением параметров мобилизация / уничтожение и влияющим на определение цели и средств не только военной стратегии, но и всей внешней политики государств, а в конечном итоге и на характер международной системы.

В.Л. Цымбурский выделяет три полномасштабных СВЦ, разделяя их на депрессивные и экспансивные, и два предшествующих им протоцикла, которые в силу ограниченности уровня эволюции вооружений и государственных структур сложно отнести к классическим СВЦ [15]:

А. 1340-1494 гг. - депрессивный военный протоцикл, в течение которого возможности уничтожения преобладают (феодальный доогнестрельный стандарт армии - рыцарь как основной военный ресурс, уникальный, до- рогостоящий, требующий длительной сложной подготовки).

Б. 1494-1648 гг. - экспансивный военный протоцикл, в течение которого возможности мобилизации преобладают (швейцарское пехотное ополчение и широкое распространение военного наемничества как практически неиссякаемого ресурса военной силы - в условиях появления даже несовершенного огнестрельного оружия с ограниченной эффективностью новый тип формирования европейских армий обесценил роль рыцарства).

I. 1648-1792 гг. - депрессивный СВЦ, возможности уничтожения преобладают (выставленные на поле боя шведским королем Густавом Адольфом легкие пушки, мушкетеры и достигнутая новыми построениями боевых порядков высокая плотность мушкетного огня позволили наносить неприемлемый урон большим и плохо обученным наемным армиям, Европа переходит к преобладанию компактной высокопрофессиональной армии и тактике ее максимального сохранения в войне).

II. 1792-1945 гг. - экспансивный СВЦ, возможности мобилизации преобладают (появление нового мобилизационного ресурса идеологии национализма, благодаря которому революционная Франция впервые выставляет на европейское поле боя массовую высоко мотивированную армию, появляется концепция «народных войн», «вооруженного народа»).

III. C 1945 г. по наши дни - депрессивный СВЦ, возможности уничтожения преобладают (создание и эволюция ядерного оружия и средств его доставки к цели обнулили смысл содержания огромных массовых армий с развернутыми мобилизационными резервами, мировая война стала невозможной из-за угрозы неизбежного взаимного уничтожения).

Таким образом, смена СВЦ обусловливается сочетанием научных открытий в сфере вооружений и развитием политических режимов, приобретающих новые возможности вовлечения в войну все более широких людских масс (национальная идеология, возможность массовой вербовки военных наемников, всеобщий воинский призыв, тотальная мобилизация и т. д.) и материальных ресурсов. Основной инструмент внешней политики государства при депрессивном СВЦ - воздействие на политическую волю оппонента 
с целью склонения к уступкам невоенным путем («мягкая сила»), основной инструмент внешней политики государства при экспансивном СВЦ- война или военная угроза, проистекающая из разницы потенциалов («жесткая сила»).

В рамках описания метода исследования на основе теории СВЦ В.Л. Цымбурского целесообразно кратко упомянуть другие взаимосвязанные элементы его концепции, составившие основу инструментария геополитического анализа.

В одной из своих работ ученый приводит образное определение: «...остров представляется как средоточие метафизической силы, в котором укрощаются силы океана безмерного, непостижимого. Остров также символизирует одиночество, изоляцию, смерть» [20, с. 34]. Россия ввиду особенностей географического положения исторически сформировалась как духовно самодостаточная цивилизация-остров, изолированная от «континентов-систем» Запада и Востока, сперва природными преградами, а затем некими геополитическими «проливами» в виде цепочки буферных государств. Но при этом сама Россия никогда не стремилась к самоизоляции. Напротив, российская политическая элита (хотя зачастую и оказывалась в ситуации «осажденной крепости», вынужденной отражать попытки военного штурма) периодически устремляла взор к западному «континенту», что выражалось элементами экспансии и контрэкспансии. Это обстоятельство сформировало особенность, характерную для политической элиты как Российской империи, так и современной Российской Федерации: увлечение геополитикой, повышенное внимание к военно-силовому ресурсу. Как отмечает российский исследователь: «Паттерн “острова России” означает полную инверсию геополитических приоритетов государства в сравнении с той их иерархией, которая характеризовала велико-имперскую эпоху» [21, с. 10].

Особенность геополитической истории России, по мнению В.Л. Цымбурского, состоит в параллельном протекании двух циклов собственно СВЦ соответствующего периода, во многом определяемого эволюцией или революцией западных военно-политических структур, и цикла российского «похищения
Европы», стремления России занять весомое место в европейской, а затем и международной политической системе. Российским исследователем выделено три макроцикла «похищения Европы», которые лишь отчасти совпадают с СВЦ: 1726-1905 гг., 1906 - конец 30-х гг., 1939-90-е гг. [22, с. 62]. Причем Россию как военно-политическую силу на европейский театр приглашает одна из противоборствующих между собой европейских сторон, но все завершается объединением замирившейся Европы и ее коллективными усилиями по «выдавливанию» России из европейского пространства [22, с. 63].

Анализ. Современный СВЦ, начавшийся с создания ядерного оружия в 1945 г., характеризуется способностью физически уничтожить даже самые территориально крупные страны. Массовая мобилизация граждан и перевод экономики «на военные рельсы» утеряли смысл, поскольку военный результат в гипотетической мировой войне будет выполнен в течение нескольких часов серией массированных ядерных ударов на всю глубину территории государства-противника, что обнуляет понятие тыла как относительно безопасной геополитической зоны. Мировая война в таких условиях становится бессмысленной и формула победы представлена в своем смягченном варианте, что обеспечило устойчивость Ялтинско-Потсдамской международной системы, основанной на геополитических итогах Второй мировой войны.

Базируясь на положениях теории СВЦ, можно предположить, что данная международная система, застрахованная от мировых войн, должна просуществовать на протяжении всего третьего СВЦ - ориентировочно до конца XXI в., когда ведущие державы найдут способ обесценить ядерную угрозу и человечество вернется в бескомпромиссную и жестокую эпоху войн, основанных на соревновании мобилизационных возможностей. Однако насколько обосновано подобное оптимистическое предположение с позиции текущей ситуации на мировой арене?

Эксперты американского исследовательского фонда Стрэтфор прогнозируют на ближайшие годы резкое ускорение гонки вооружений между Россией, США и Китаем и, соответственно, «напряженный геополитический 
климат» [23]. Как отмечал еще в 90-х гг. XX в. Э. Тоффлер, с 70-х гг. ХХ в. эволюция вооружений в классическом, инженерно-техническом понимании потеряла смысл: «В гонке вооружений за увеличение дальнобойности, скорости и поражающей силы оружия были достигнуты уже все практически значимые пределы» $[13$, с. 76$]$. Р. Макнамара признавал, что все попытки военных США найти выход из «ядерного пата» на доктринальном уровне потерпели неудачу, равно как лишенной смысла оказалась и количественная гонка вооружений: в разгар Карибского кризиса 1962 г. США имели превосходство над СССР в ядерном оружии в соотношении 17:1, но не видели возможности выиграть войну [7, с. 19]. Качественная эволюция атомного оружия появление вслед за ядерными термоядерных (водородных), а затем и нейтронных боезарядов, - принципиально не изменила ситуацию, не смогла дать неоспоримого преимущества одной из соперничающих сторон. Однако поиски способов обхода феномена «ядерного пата» американская военно-политическая мысль продолжает настойчиво и постоянно [6].

Смена «депрессивного» СВЦ на «экспансивный», открывающий путь к мировым войнам, невозможна без обнуления уникальной поражающей способности доминирующего типа вооружений, что, в свою очередь, было невозможно без научно-технических открытий прорывного уровня. Как изобретение пороха и внедрение огнестрельного оружия обнулило военную ценность рыцарских лат и феодальных замков, так овладение ядерной энергией в значительной степени маргинализировало все виды вооружений, основанных на огнестрельном принципе. Организация Варшавского договора имела безусловное преимущество перед Североатлантическим альянсом в танках, авиации, численности вооруженного стрелковым оружием личного состава армий, однако так и не смогла реализовать данный потенциал в глобальной геополитической игре, в итоге пустив на утилизацию значительное число устаревших со временем танков, самолетов, кораблей, подводных лодок и прекратила существование.

Опираясь на аналогию, можно предположить, что дорога к смене современного СВЦ неизбежно пролегает через военно-техническую нейтрализацию ядерного оружия. Наиболее рациональным решением было бы освоение принципиально новых видов энергии, которую можно использовать в военных целях. Однако научно-техническая революция с последней четверти $\mathrm{XX}$ в. развернула прогресс цивилизации в сторону тотальной компьютеризации и связанной с ней автоматизации и цифровизации всех сфер деятельности человека. Эволюция технической аппаратуры направлена на ускорение процесса сбора, обработки и передачи информации, расширения объемов ее хранения. Ожидаемое в ближайшие годы внедрение стандарта передачи $5 \mathrm{G}$ в сочетании с реализацией проекта OneWeb по обеспечению всепланетарного доступа пользователей к широкополосному и в перспективе «бесплатному» Интернету станет серьезным шагом к стиранию границы между реальной и виртуальной сферами человеческого бытия, что отразится и на военной его составляющей. Основные усилия инженерной мысли направились не на поиск новых видов энергии, а на поиск технологий построения виртуального симулякра любого материального объекта или процесса с возможностью последующих манипуляций над ним. Значительное внимание военные эксперты теперь уделяют осмыслению особенностей противостояния в кибернетической сфере, характерными примерами чего являются регулярные научно-аналитические обзоры, выполняемые одной из ведущих американских «think tanks» в области военно-политической безопасности - корпорацией РЭНД [29; 30].

Учитывая упомянутые технологические тренды, можно предположить, что революционного «обнуления» доминирующего значения ядерного оружия в форме одного научного открытия прорывного характера не будет. Но это произойдет эволюционным путем, в форме серии новых научно-технических разработок, каждая из которых в отдельности не сможет сыграть ключевой роли, но суммарно они будут обеспечивать нужный эффект. Основными из разработок подобного рода автору данной статьи видятся следующие:

- качественное повышение возможностей получения точных разведывательных данных в форме дистанционного съема информа- 
ции, когда у потенциального противника не останется возможности скрыть места развертывания ядерного оружия ни на поверхности земли, ни в глубине океана, ни в толще горных массивов, а все передвижения войск будут отслеживаться в режиме реального времени. Мир превратится в идеальный паноптикум Мишеля Фуко с многослойно дублируемыми системами «всеподнадзорности»;

- развитие систем высокоточного оружия на основе технологий искусственного интеллекта, позволяющего преодолевать защиту военных объектов, в том числе баз развертывания оружия массового поражения;

- роботизация основных видов вооружений и максимальное удаление человека непосредственно с поля боя;

- появление «роевого оружия», состоящего из многочисленных небольших беспилотных летательных аппаратов, обессмысливающих состоящие на вооружении современные комплексы локальной противоракетной обороны статических стратегических объектов. При этом мобильные ракетные комплексы типа РТ-2ПМ2 «Тополь-М» и РС-24 «Ярс» также лишатся неуязвимости ввиду развития средств электронной спутниковой разведки;

- размещение высокоточного оружия на околоземой орбите;

- оснащение ядерным боезарядом малой мощности межконтинентальных баллистических ракет (к октябрю 2019 г. в ВМФ США поступит на вооружение ядерная боеголовка W76-2 мощностью в 5 килотонн тротилового эквивалента для оснащения ракет Trident II, что в три раза слабее, чем боезаряд, сброшенный на Хиросиму);

- появление гиперзвуковых крылатых ракет (российский комплекс «Авангард», американский комплекс X-51A Waverider);

- развитие кибернетического оружия, направленного на выведение из строя автоматизированных систем управления войсками, сбора, обработки и трансляции информации, необходимой для принятия решений военно-политического характера;

- развертывание глобальной системы противоракетной обороны. Именно данный из перечисленных факторов сейчас находится в фокусе повышенного внимания российского руководства, военно-политических аналитиков
[5] и является объектом приложения усилий по противодействию, хотя недоучет значения остальных факторов может стать стратегической ошибкой;

- новые перспективы развития биологического оружия, основанные на достижениях в изучении генома человека, что позволит «конструировать» болезнетворные вирусы, избирательно учитывающие половозрастные и расовые особенности потенциальных жертв.

В.Л. Цымбурский в 90-е гг. ХХ в. выдвинул прогноз, согласно которому «...нас ждал бы в первой четверти XXI в. большой прилив милитаристской активности, подстегиваемый благоприятными политическими обстоятельствами и техническими новшествами, однако не вырывающийся за рамки нынешнего эталона победы - то есть влияния на волю противника вместо ее сокрушения» [15, с. 49]. Но анализ последующих событий позволяет предположить развитие более серьезного тренда, чем охвативший элиты великих держав милитаристский психоз. Прогнозируя скорый кумулятивный эффект в сфере военно-технических открытий, США приступили к планомерному демонтажу международной системы безопасности, основанной на двусторонних и многосторонних договорах, действовавших в рамках Ялтинско-Потсдамских принципов.

Ключевыми вехами на данном пути в 2001 г. стал выход США из Договора об ограничении систем противоракетной обороны от 1972 г. и объявленный на 2019 г. выход США из Договора о ликвидации ракет средней и меньшей дальности. Можно упомянуть разрыв или нарушение со стороны США целой серии не столь эпохальных, но важных для поддержания системы международной безопасности договоров: совместный всеобъемлющий план действий по иранской ядерной программе, отказ от ратификации Договора о всеобъемлющем запрете ядерных испытаний, угроза отказа от Договора по стратегическим наступательным вооружениям [2, с. 4].

С 80-х гг. ХХ в. СССР / РФ совместно с США поэтапно сократили свои ядерные арсеналы [1, с. 5]. Согласно данным доклада Стокгольмского института исследования проблем мира Россия к настоящему времени может обладать примерно 7000 единицами ядерного оружия, а США - 6800 единицами 
[31, p. 1]. Но, если рассматривать официальные данные, которыми обмениваются Россия и США в рамках договора по Стратегическим наступательным вооружениям, реальные показатели по стратегическим вооружениям, пригодным к немедленному применению, выглядят намного скромнее. Количество развернутых стратегических носителей ядерного оружия (межконтинентальные баллистические ракеты, подводные лодки и тяжелые бомбардировщики) для США составляет 659 единиц и для России - 517 по данным на 1 сентября 2018 г. [27].

Вашингтон в перспективе получает возможность обеспечить высокую степень вероятности перехвата запущенных российских стратегических носителей ядерного оружия и разместить в европейских странах-партнерах по НАТО ракеты средней и малой дальности. Складывающаяся ситуация может породить у американского руководства соблазн нанесения упреждающего ядерного удара ракетами средней и малой дальности по российским военным объектам и центрам управления войсками, затем глобальная система противоракетной обороны перехватит те из 517 стратегических носителей ядерных боезарядов российской стороны, которые уцелеют и будут запущены в попытке ответного удара. Именно этим, на наш взгляд, вызвана крайне острая реакция российского руководства на выход США из договоренностей [11]. Неблагоприятный для России геостратегический расклад еще больше ухудшится в случае, если США сумеют привести к власти в республиках Средней Азии антироссийские политические режимы, согласные разместить на своей территории американское оружие, что создаст возможность обстрела ракетами средней и малой дальности российских объектов не только в европейской части страны, но уже и в Сибири.

Негативный военно-технический тренд российское руководство вскрыло своевременно, что подтверждается резким тоном «Мюнхенской речи» российского Президента В.В. Путина в 2007 г. [9, с. 36]. Но экономические возможности США и России сейчас несопоставимы, что вынудило российское руководство параллельно с модернизацией существующих и разработкой новых собствен- ных систем вооружений искать и асимметричные ответы на навязанную военно-технологическую гонку. Асимметричность российского ответа выразилась в духе классической геополитики - постановка под контроль стратегически важных сухопутных территорий с помощью армии. В 2008 г. российские войска наносят военное поражение Грузии, сохраняя контроль над Кавказским горным хребтом и создавая Тбилиси территориальный спор, формально блокирующий возможность вступления в НАТО. В 2014 г. «вежливые люди» обеспечивают силовое прикрытие процедуре воссоединения Крыма с Россией, создавая для Киева аналогичный территориальный спор.

Обратившись к анализу доктринальных документов США, декларирующих текущие принципы американской военной политики, можно выделить следующее:

- американское понимание военной мощи как «дополнения традиционных инструментов дипломатии, обеспечивающих Президенту Соединенных Штатов и внешнеполитическому ведомству комфортных условий для ведения переговоров с позиции силы» [24];

- восприятие Китая и России как ключевых соперников, стремящихся «ограничить геополитическое лидерство Соединенных Штатов и изменить баланс сил в свою пользу» [25];

- ключевыми военно-техническими решениями, позволяющими США «нивелировать» военную мощь Китая и России, являются развертывание глобальной системы противоракетной обороны (в том числе включая технологии, позволяющие «нейтрализовать» [25] китайские и российские ракеты до их запуска) и милитаризация космического и кибернетического пространств;

- поддержка «биомедицинских инноваций» [25], то есть de facto разработка новых поколений биологического оружия;

- наращивание численности и интенсификация программ подготовки личного состава вооруженных сил США [25] (одним из первых практических шагов в этой сфере стало воссоздание ранее расформированного в связи с окончанием «холодной войны» Второго Атлантического флота США, нацеленного, в первую очередь, на противодействие России в северных морях и акватории Ледовитого океана); 
- защита «инновационной базы США от конкурентов» [25], то есть отсечение неугодных государств от передовых научно-технических разработок Запада и создание недоступной им внутризападной «системы обмена знаниями» [25];

- готовность к расширению «географии боевых действий», когда в войнах будущего армии США придется одновременно сражаться как в удаленных регионах планеты, так и у своей государственной границы [24].

Сравнивая данные принципы с приведенными выше современными тенденциями в развитии вооружений, можно констатировать, что США являются инициатором, сторонником и практическим реализатором большинства из них, то есть активно готовятся к войне нового формата, включающей в себя комбинированное применение как ядерного, так и неядерного оружия.

Уделяется большое внимание идеологическому обоснованию ведущейся в США модернизации стратегических ядерных сил. Выпущенный в феврале 2018 г. Пентагоном «Обзор ядерной политики США» содержит утверждение, согласно которому, хотя запасы ядерного оружия по сравнению с периодом «холодной войны» и были сокращены на 85 \%, угроза ядерного нападения на США велика, как никогда ранее [26]. В изданной аппаратом директора национальной разведки в январе 2019 г. «Стратегии национальной разведки Соединенных Штатов Америки» подчеркивается озабоченность возможностью противодействия американской программе контроля над космическим пространством [32].

Анализ аналогичных доктринальных документов России показывает, что военно-политическое руководство по-прежнему воспринимает ядерное орудие в традиционном ключе - исключительно как политический фактор сдерживания [12], при этом «недопущение ядерного военного конфликта... положено в основу военной политики Российской Федерации» [3]. Очевидно, что на фоне антироссийских экономических санкций со стороны западных стран, постепенного снижения уровня жизни российского населения, формирования на границах страны антироссийских геополитических плацдармов (Украина, Грузия, Прибалтика), готовых при благоприятных для них условиях стать вектором военной экспансии, советское ядерное наследие видится как универсальная гарантия от нападения, а вероятностная нейтрализация его потенциала как основная угроза, сравнимая с военной катастрофой. Отсюда проистекает острая реакция российского руководства на действия США: от демонстрации новейших стратегических разработок («Сармат», «Авангард», «Кинжал») во время Послания Президента Российской Федерации В.В. Путина Федеральному Собранию 1 марта 2018 г. [11] до заявления министра иностранных дел РФ С.В. Лаврова о росте риска применения ядерного оружия [14]. Российские эксперты Центра военно-политических исследований при МГИМО (У) МИД РФ указывают на высокую вероятность перерастания силового противостояния между Западом и другими цивилизациями (включая Россию) в военное противоборство в 2020-е гг. [10].

В завершении анализа параметров текущего «депрессивного» СВЦ необходимо кратко рассмотреть ситуацию с мобилизационными возможностями современных государств. Великие прорывы к возможностям мобилизации, превосходящим поражающую мощь господствующих вооружений и позволяющим длительный период выставлять на поле боя новые людские и материальные ресурсы, объясняются, по предположению В.Л. Цымбурского, феноменом «эмансипации» общества, когда в результате разрушения традиционных, сословных, корпоративных социальных структур высвобождаются значительные людские массы [15], способные запитать войска. Именно на «экспансивных» СВЦ (преобладание мобилизации над уничтожением) рождаются великие мессианские проекты геополитических захватов и идеологии силового переустройства мира.

В основе мобилизационного успеха находится не только способность государственного аппарата эффективно учитывать и перераспределять находящиеся под его контролем людские и материальные ресурсы, но и идеологическое обоснование их экстремального использования. Вторая половина XX в. охарактеризовалась падением влияния политических идеологий, несущих в себе мобилизационный потенциал, на смену которым прихо- 
дит консьюмеризм, выражающий психологию «общества потребления». Среднестатистический житель великой державы теперь озабочен не поиском подвигов или участием в проектах глобального переустройства мира, а выстраиванием пространства личной безопасности и комфорта. Военное противоборство стало уделом преимущественно ограниченного круга профессионалов, ведущих между собой боевые действия на территории третьих стран.

Тезис о том, что ядерное оружие сделало невозможным мировые войны, а значит и обессмыслило существование массовых армий и мобилизационного ресурса, не нов. Новыми являются как военные (рассмотренные выше), так и социально-политические технологии, позволяющие если не нейтрализовать полностью, то значительно снизить роль ядерного орудия как сдерживающего большую войну фактора. К технологиям данного рода можно отнести:

- манипулирование потоками беженцев, меняющих не только демографическую ситуацию, но потенциально и сам цивилизационный культурно-исторический код попавших под демографическую «атаку» государств;

- стратегия «гибридных войн», позволяющая без формального акта объявления войны создавать губительное давление на экономику противника, его информационно-культурную сферу и вооруженные силы;

- ослабление в ходе глобализации национальных идентичностей, ведущее к своеобразному «расслоению» социально-политического бытия народов, когда на одном полюсе формируется «интернационал элит» со своим корпоративным мировоззрением и взаимозависимыми интересами, а на другом - «народные массы», чье политическое сознание с помощью информационных технологий постепенно погружается в неотрадиционализм, взращивается «образ врага» и культивируется милитаристский психоз. Элиты великих держав, движимые неформальными обязательствами друг перед другом, в состоянии геополитического конфликта могут и не пойти на самоубийственное полномасштабное применение ядерного оружия, но позволить «народным массам» сойтись между собой на поле боя в затяжной кровавой схватке. Символично, что с
2017 г. даже в нейтральной Швеции возобновилось комплектование вооруженных сил по принципу всеобщей воинской повинности, которая распространилась и на женщин с расчетом увеличить численность военнослужащих втрое [4, с. 80]. Согласно оценке Шведского института оборонных исследований армия России в настоящий момент тоже перешла на подготовку к участию в длительных войнах на большой территории, хотя ранее, как и другие, больше ориентировалась на скоротечные локальные конфликты [28] - очевидно, политические элиты современных государств начинают приходить к пониманию возрастающей роли мобилизационного фактора.

Результаты. Таким образом, мы можем сделать следующие выводы:

1. Теория В.Л. Цымбурского о сверхдлинных военных циклах, разработанная в 90-х гг. XX в., может стать новым элементом методологического инструментария современной геополитики и найти практическое применение при изучении тенденций развития межгосударственных отношений с акцентом на их военно-политическую составляющую, что позволит выявить новые вызовы и угрозы действующей системе международной безопасности.

2. Эволюция военных и социально-политических технологий современного межгосударственного противоборства позволит великим державам (США, Россия, Китай) в ближайшие десять лет вплотную подойти к возможности частичной или полной нейтрализации фатальных последствий ядерного удара со стороны оппонента, что обесценит роль ядерного орудия как основного сдерживающего военно-политического фактора на мировой арене.

3. Изменение роли ядерного оружия приведет к досрочному завершению «депрессивного» (основанного на превалировании возможностей уничтожения) текущего СВЦ и откроет возможность начала «экспансивного» СВЦ с превалирующей ролью мобилизации, развитием агрессивных политических идеологий, милитаризацией массового сознания граждан.

4. Содержанием «экспансивного» СВЦ может стать попытка великих держав предпринять геополитический передел мира, пере- 
смотреть сложившийся на мировой арене status quo. Велика вероятность, что данный пересмотр может быть проведен методом широкомасштабной мировой войны с ограниченным применением ядерного оружия или совсем без применения такового. Элиты великих держав при этом могут соблюдать неформальные договоренности по взаимоуважению своих интересов, основные тяготы войны лягут на плечи рядовых граждан. Упрощенной моделью прогнозируемых событий являются современные «гибридные войны», при которых ведутся боевые действия, гибнут как мирные граждане, так и наемники-комбатанты и кадровые военные, государства теряют и приобретают территории, но при этом продолжают экономическое сотрудничество и даже не всегда разрывают дипломатические отношения.

5. Один из эффективных способов сохранения мира в данных условиях состоит в развитии институтов общественной дипломатии, расширении многосторонних международных контактов на уровне негосударственных акторов. Особое значение приобретает совместный поиск надгосударственной общецивилизационной объединяющей идеи, которой может выступить коллективная историческая память о Второй мировой войне, преступлениях нацизма, осознание необходимости недопущения подобных событий в будущем. Ведущая роль в формировании, развитии и укреплении данной объединяющей идеи объективно может принадлежать именно России, многонациональный социум которой внес решающий вклад в разгром Гитлеровской Германии, восстановление мира на земле и бережно хранит память о тех событиях.

\section{СПИСОК ЛИТЕРАТУРЫ}

1. Арбатов, А. Трансформация ядерного сдерживания / А. Арбатов // Мировая экономка и международные отношения. - 2018. - № 7. - С. 5-16.

2. Афанасьев, С. Военно-стратегические реалии международной обстановки: вызовы и угрозы безопасности России / С. Афанасьев // Зарубежное военное обозрение. - 2019. - № 1. - С. 3-10.

3. Военная доктрина Российской Федерации. Утверждена Президентом РФ В.В. Путиным 25.12.2014 № Пр-2976 // Доступ из справ.-правовой системы «Гарант».
4. Воронов, К. «Полтавский синдром» Швеции: тяжелое политическое наследие / К. Воронов // Мировая экономика и международные отношения. -2018 . - № 12. - С. 75-82.

5. Калядин, А. Реальная угроза или фальшивая страшилка? (О ставке на ядерный обезоруживающий удар по РФ) / А. Калядин // Мировая экономика и международные отношения. - 2017. № 12. - С. 18-26.

6. Купач, О. С. Анализ программы США «Неядерный быстрый глобальный удар» / О. С. Купач // Военная мысль. - 2018. - № 12. - С. 18-22.

7. Макнамара, Р. Путем ошибок - к катастрофе. Опыт выживания в первом веке ядерной эры / Р. Макнамара. - М. : Наука, 1988. - 149 с.

8. Межуев, Б. В. Вадим Цымбурский: от конъюнктур земли к конъюнктурам времени / Б. В. Межуев // Метод. - 2011. - № 2. - С. 321-345.

9. Никитин, А. И. Современный миропорядок: его кризис и перспективы / А. И. Никитин // Полис. Политические исследования. - 2018. - № 6. -С. 32-46.

10. Подберезкин, А. И. Мир и война в XXI веке: опыт долгосрочного прогнозирования развития международных отношений / А. И. Подберезкин, М. В. Харкевич. - М. : МГИМО-Университет, 2015. $581 \mathrm{c}$.

11. Путин, В. В. Послание Президента Федеральному Собранию / В. В. Путин. - Электрон. текстовые дан. - Режим доступа: http://www.kremlin.ru/ events/president/news/56957 (дата обращения: 05.02.2019). - Загл. с экрана.

12. Стратегия национальной безопасности Российской Федерации : утв. Президентом РФ В. В. Путиным 31.12.2015 г. № 683. - Доступ из справ.-правовой системы «Гарант».

13. Тоффлер, Э. Война и антивойна. Что такое война и как с ней бороться. Как выжить на рассвете XXI века / Э. Тоффлер, Х. Тоффлер. - М. : АСТ, 2005. $-412 \mathrm{c}$.

14. Филипенок, А. Лавров заявил о росте риска применения ядерного оружия из-за действий США / А. Филипенок // РБК. - Электрон. текстовые дан. - Режим доступа: https://www.rbc.ru/politics/04/ 02/2019/5c57f7269a7947f7feaa4bfb?from=main (дата обращения: 03.02.2019). - Загл. с экрана.

15. Цымбурский, В. Л. Сверхдлинные военные циклы и мировая политика / В. Л. Цымбурский // Полис. Политические исследования. - 1996. № 3. - С. 27-55.

16. Цымбурский, В. Л. Геополитика как мировидение и род занятий / В. Л. Цымбурский // Полис. Политические исследования. - 1999. - № 4. - С. 7-28.

17. Цымбурский, В. Л. Дважды рожденная «Евразия» и геостратегические циклы России / В. Л. Цымбурский // Вестник Евразии. - 2003. № 4. - C. 5-33. 
18. Цымбурский, В. Л. Как живут и умирают международные конфликтные системы (Судьба Балтийско-Черноморской системы в XVI-XX веках) / В. Л. Цымбурский // Полис. Политические исследования. - 1998. - № 4. - С. 52-73.

19. Цымбурский, В. Л. Морфология российской геополитики и динамика международных систем XVIII-XX вв. / В. Л. Цымбурский // Тетради по консерватизму. -2015 . - № 1. - С. 50-107.

20.Цымбурский, В. Л. От великого острова Русии... (К прасимволу российской цивилизации) / В. Л. Цымбурский // Полис. Политические исследования. - 1997. - № 6. - С. 34-56.

21. Цымбурский, В. Л. Остров Россия (Перспективы российской геополитики) / В. Л. Цымбурский // Полис. Политические исследования. - 1993. № 5. - C. 6-23.

22. Цымбурский, В. Л. «Европа-Россия»: «третья осень» системы цивилизаций / В. Л. Цымбурский // Полис. Политические исследования. - 1997. № 2. - С. 56-76.

23. Annual Forecast $2019 / /$ Stratfor. - Electronic text data. - Mode of access: https://worldview.stratfor. com/article/2019-annual-forecast-geopoliticsintelligence-global-risk (date of access: 22.01.2019). Title from screen.

24. National Defense Strategy of The United States of America 2018// U.S. Department of Defense. Electronic text data. - Mode of access: https://dod. defense.gov/Portals/1/Documents/pubs/2018National-Defense-Strategy-Summary.pdf (date of access: 04.02.2019). - Title from screen.

25. National Security Strategy of the United States of America. December 2017 // The White House. - Electronic text data. - Mode of access: https:// www.whitehouse.gov/wp-content/uploads/2017/12/ NSS-Final-12-18-2017-0905.pdf (date of access: 05.02.2019). - Title from screen.

26. Nuclear Posture Review - February 2018 // Department of Defense United States of America. Electronic text data. - Mode of access: https:// media.defense.gov/2018/Feb/02/2001872886/-1/-1/1/ 2018-nuclear-posture-review-final-report.pdf(date of access: 9.01.2019). - Title from screen.

27. New Start Treaty Aggregate Numbers of Strategic Offensive Arms. The U.S. Data in This Fact Sheet Comes from the Exchange of Data Required by the Treaty. Both Sets of Data are Current as of September 1, 2018 // U.S. Department of State. Electronic text data. - Mode of access: https:// www.state.gov/t/avc/newstart/286466.htm (date of access: 22.01.2019). - Title from screen.

28. Norberg, J. Training for War - What Military Exercises 2009-2017 Say About the Fighting Power of Russia's Armed Forces / J. Norberg // Swedish Defence Research Agency. - Electronic text data. - Mode of access: https://www.foi.se/rapportsammanfattning? reportNo=FOI-R-4627-SE (date of access: 07.02.2019). Title from screen.

29. Paul, C. The Russian "Firehose of Falsehood" Propaganda Model / C. Paul, M. Matthews // RAND Corporation. - Electronic text data. - Mode of access: https://www.rand.org/content/dam/rand/pubs/ perspectives/pe100/pe198/rand_pe198.pdf (date of access: 10.01.2019). - Title from screen.

30. Radin, A. Russian Views of the International Order / A. Radin, C. Reach. - Santa Monica, Calif. : Published by the RAND Corporation, 2017. - $124 \mathrm{p}$.

31. Shannon, N. Trends in World Nuclear Forces. SIPRI Fact Sheet, July 2017 / N. Shannon, K. Kristensen. - Electronic text data. - Mode of access: https://www.ethz.ch/content/dam/ethz/specialinterest/gess/cis/center-for-securities-studies/ resources/docs/SIPRI\%20Trends\%20in \%20 World\%20Nuclear\%20Forces,\%202016.pdf (date of access: 02.01 .2019$)$. - Title from screen.

32. The National Intelligence Strategy of the United States of America, 2019// Office of the Director of National Intelligence. - Electronic text data. - Mode of access: https://www.dni.gov/files/ODNI/documents/ National_Intelligence_Strategy_2019.pdf (date of access: 07.02.2019). - Title from screen.

\section{REFERENCES}

1. Arbatov A. Transformatsiya yadernogo sderzhivaniya [Transformation of Nuclear Deterrence]. Mirovaya ekonomika $i$ mezhdunarodnye otnosheniya, 2018, no. 7, pp. 5-16.

2. Afanasyev S. Voenno-strategicheskie realii mezhdunarodnoy obstanovki: vyzovy i ugrozy bezopasnosti Rossii [Military-Strategic Realities of the International Situation: Challenges and threats to Russia's Security]. Zarubezhnoe voennoe obozrenie, 2019, no. 1, pp. 3-10.

3. Voennaya doktrina Rossiyskoy Federatsii: utverzhdena Prezidentom RF V. V. Putinym 25.12.2014 № Pr-2976 [Military Doctrine of the Russian Federation. Approved by President of the Russian Federation V.V. Putin on 25 December, 2014 no. Pr-2976]. Spravochno-pravovaya sistema «Garant». URL: http:/ /www. garant.ru (accessed 12 January 2019).

4. Voronov K. «Poltavskiy sindrom» Shvetsii: tyazheloe politicheskoe nasledie [Sweden's Poltava Syndrome: a Heavy Political Legacy]. Mirovaia ekonomika i mezhdunarodnye otnosheniya, 2018, no. 12, pp. 75-82.

5. Kaliadin A. Realnaya ugroza ili falshivaya strashilka? (O stavke na yadernyy obezoruzhivayushchiy udar po RF) [A Real Threat or a Fake Horror Story? (About the Stake on the Nuclear Disarming Strike on 
the Russian Federation)]. Mirovaya ekonomika $i$ mezhdunarodnye otnosheniya, 2017, no. 12, pp. 18-26.

6. Kupach O.S. Analiz programmy SShA «Neyadernyy bystryy globalnyy udar» [Analysis of the US Program "Non-Nuclear Fast Global Strike"]. Voennaya mysl, 2018, no. 12, pp. 18-22.

7. Maknamara R. Putem oshibok-k katastrofe. Opyt vyzhivaniya $v$ pervom veke yadernoy ery [By Mistake - to Disaster. First-Century Nuclear Era Survival Experience]. Moscow, The Science Publ., 1988. 149 p.

8. Mezhuev B.V. Vadim Tsymburskiy: ot konyunktur zemli k konyunkturam vremeni [Vadim Tsymbursky: From Land Conjuncture to Time Conjuncture]. Metod, 2011, no. 2, pp. 321-345.

9. Nikitin A.I. Sovremennyy miroporyadok: ego krizis i perspektivy [The Modern World Order: Its Crisis and Prospects]. Polis. Politicheskie issledovaniya, 2018, no. 6, pp. 32-46.

10. Podberezkin A.I., Kharkevich M.V. Mir i voyna v XXI veke: opyt dolgosrochnogo prognozirovaniya razvitiya mezhdunarodnykh otnosheniy [Peace and War in the $21^{\text {st }}$ Century: Experience of Long-Term Forecasting the Development of International Relations]. Moscow, MGIMO-Universitet Publ., 2015. 581 p.

11. Putin V.V. Poslanie Prezidenta Federalnomu Sobraniyu [President's Message to the Federal Assembly]. President of Russia. URL: http://www. kremlin.ru/events/president/news/56957 (accessed 5 February 2019).

12. Strategiya natsionalnoy bezopasnosti Rossiyskoy Federatsiy: utverzhdena Prezidentom RF V.V. Putinym 31.12.2015 no. 683 [National Security Strategy of the Russian Federation. Approved by the President of the Russian Federation V.V. Putin 12/31/2015 no. 683]. Spravochno-pravovaya sistema «Garant». URL: http://www.garant.ru (accessed 01 February 2019).

13. Toffler E., Toffler Kh. Voyna i antivoyna. Chto takoe voyna $i$ kak $s$ ney borotsya. Kak vyzhit na rassvete XXI veka [War and Anti-War. What is War and How to Fight it. How to Survive at Dawn of the $21^{\text {st }}$ Century]. Moscow, AST Publ., 2005. 412 p.

14. Filipenok A. Lavrov zayavil o roste riska primeneniya yadernogo oruzhiya iz-za deystviy SShA [Lavrov Announces Increased Risk of Using Nuclear Weapons due to USActions]. RBK. URL://www.rbc.ru/ politics/04/02/2019/5c57f7269a7947f7feaa 4bfb?from=main (accessed 03 February 2019).

15. Tsymburskiy V.L. Sverkhdlinnye voennye tsikly i mirovaya politika [Ultra-Long War Cycles and World Politics]. Polis. Politicheskie issledovaniya, 1996, no. 3, pp. 27-55.

16. Tsymburskiy V.L. Geopolitika kak mirovidenie i rod zanyatiy [Geopolitics as a Mode of Vision of the World and a Occupation]. Polis. Politicheskie issledovaniya, 1999, no. 4, pp. 7-28.
17. Tsymburskiy V.L. Dvazhdy rozhdennaya «Evraziya» i geostrategicheskie tsykly Rossii [TwiceBorn "Eurasia" and the Geostrategic Cycles of Russia]. Vestnik Evrazii, 2003, no. 4, pp. 5-33.

18. Tsymburskiy V.L. Kak zhivut i umirayut mezhdunarodnye konfliktnye sistemy (Sudba Baltiisko-Chernomorskoy sistemy v XVI-XX vekakh) [How Iternational Conflict Systems Live and Die (The Fate of the Baltic and Black Sea System in the $16^{\text {th }}$ to the $20^{\text {th }}$ Centuries)]. Polis. Politicheskie issledovaniya, 1998, no. 4, pp. 52-73.

19. Tsymburskiy V.L. Morfologiya rossiyskoy geopolitiki i dinamika mezhdunarodnykh sistem XVIIIXX vv. [The Morphology of Russian Geopolitics and the Dynamics of International Systems of the $18^{\text {th }}$ to the $20^{\text {th }}$ Centuries]. Tetradi po konservatizmu, 2015, no. 1 , pp. 50-107.

20. Tsymburskiy V.L. Ot velikogo ostrova Rusii... (K prasimvolu rossiyskoy tsivilizatsii) [From the Great Island of Russia. To the Prasymbol of the Russian Civilization)]. Polis. Politicheskie issledovaniya, 1997, no. 6, pp. 34-56.

21. Tsymburskiy V.L. Ostrov Rossiya (Perspektivy rossiyskoy geopolitiki) [Island Russia. (Prospects for Russian Geopolitics)]. Polis. Politicheskie issledovaniya, 1993, no. 5, pp. 6-23.

22. Tsymburskiy V.L. «Evropa-Rossiya»: «tretya osen" sistemy tsivilizatsii ["Europe - Russia": "The Third Autumn" of the System of Civilizations]. Polis. Politicheskie issledovaniya, 1997, no. 2, pp. 56-76.

23. Annual Forecast 2019. Stratfor. URL: https:// worldview.stratfor.com/article/2019-annual-forecastgeopolitics-intelligence-global-risk (accessed 22 January 2019).

24. National Defense Strategy of The United States of America 2018. U.S. Department of Defense. URL: https://dod.defense.gov/Portals/1/Documents/ pubs/2018-National-Defense-Strategy-Summary.pdf (accessed 4 February 2019).

25. National Security Strategy of the United States of America. December 2017. The White House. URL: https://www.whitehouse.gov/wp-content/ uploads/2017/12/NSS-Final-12-18-2017-0905.pdf (accessed 5 February 2019).

26. Nuclear Posture Review. February 2018. Department of Defense United States of America. URL: https://media.defense.gov/2018/Feb/02/2001872886/1/-1/1/2018-nuclear-posture-review-final-report.pdf (accessed 9 January 2019).

27. New Start Treaty Aggregate Numbers of Strategic Offensive Arms. The U.S. Data in This Fact Sheet Comes from the Exchange of Data Required by the Treaty. Both Sets of Data are Current as of September 1, 2018. U.S. Department of State. URL: https://www.state.gov/t/avc/newstart/286466.htm (accessed 22 January 2019). 


\section{МЕЖДУНАРОДНАЯ БЕЗОПАСНОСТЬ}

28. Norberg J. Training for War - What Military Exercises 2009-2017. Say About the Fighting Power of Russia's Armed Forces. Swedish Defence Research Agency. URL: https://www.foi.se/rapportsamman fattning? reportNo=FOI-R-4627-SE (accessed 7 February 2019).

29. Paul C., Matthews M. The Russian "Firehose of Falsehood" Propaganda Model. RAND Corporation. URL: https://www.rand.org/content/dam/rand/pubs/ perspectives/pe100/pe198/rand pe198.pdf (accessed 10 January 2019).

30. Radin A., Reach C. Russian Views of the International Order. Santa Monica, Calif., Published by the RAND Corporation, 2017. $124 \mathrm{p}$.
31. Shannon N., Kristensen, K. Trends in World Nuclear Forces. SIPRI Fact Sheet, July 2017. URL: https://www.ethz.ch/content/dam/ethz/specialinterest/gess/cis/center-for-securities-studies/ resources/docs/SIPRI\%20 Trends\%20in\%20World\% 20 Nuclear\%20Forces, \%202016.pdf (accessed 2 January 2019).

32. The National Intelligence Strategy of the United States of America, 2019. Office of the Director of National Intelligence. URL: https:// www.dni.gov/files/ODNI/documents/National Intelligence_Strategy_2019.pdf(accessed 7 February 2019).

\section{Information about the Author}

Ilya L. Morozov, Doctor of Sciences (Politics), Associate Professor, Professor, Department of Public Administration and Political Science, Volgograd Institute of Management, Branch of Russian Presidential Academy of National Economy and Public Administration, Gagarina St., 8, 400131 Volgograd, Russian Federation, politkon@mail.ru, https://orcid.org/0000-0001-8241-5880

\section{Информация об авторе}

Илья Леонидович Морозов, доктор политических наук, доцент, профессор кафедры государственного управления и политологии, Волгоградский институт управления - филиал Российской академии народного хозяйства и государственной службы при Президенте РФ, ул. Гагарина, 8 , 400131 г. Волгоград, Российская Федерация, politkon@mail.ru, https://orcid.org/0000-0001-8241-5880 